\title{
STOCK ASSESSMENT OF PROCHILODUS NIGRICANS (ACTINOPTERYGII: CHARACIFORMES: PROCHILODONTIDAE) USING TWO DISTINCT ALGORITHMS, IN THE CONTEXT OF A SMALL-SCALE AMAZONIAN FISHERY
}

\author{
Michel F. CATARINO ${ }^{1}$, James R. KAHN², and Carlos E.C. FREITAS ${ }^{1 *}$ \\ ${ }^{1}$ Department of Fisheries Sciences, Federal University of Amazonas, Manaus AM, Brazil \\ ${ }^{2}$ Washington and Lee University, Lexington VA, USA
}

Catarino M.F., Kahn J.R., Freitas C.E.C. 2019. Stock assessment of Prochilodus nigricans (Actinopterygii: Characiformes: Prochilodontidae) using two distinct algorithms, in the context of a small-scale Amazonian fishery. Acta Ichthyol. Piscat. 49 (4): 373-380.

\begin{abstract}
Background. Despite the importance of inland fishery, assessments of exploited inland stocks have relied on datadeficient databases, mainly in developing countries. In this paper, we employed two distinct analytical methods to evaluate the stock status of Prochilodus nigricans Spix et Agassiz, 1829, the most important fish in the Amazonian freshwater landings. In this study, we intended to test the sustainability of small-scale fisheries comparing two different methods.

Materials and methods. The population dynamic of P. nigricans was studied using length and weight data for fish caught in Manacapuru Lake and the lower stretch of the Solimões River. Estimates of maximum sustainable yield and corresponding fishing mortality for 2012 and 2013, using Beverton-Holt curve, indicated an overfishing status for both years. At the same region, fishers were interviewed and their knowledge on the P. nigricans stock status was assessed using a stock assessment methodology based on fishers' knowledge, known as ParFish.

Results. Both yield per recruit curves employed to assess the stock status of P. nigricans in 2012 and 2013 and ParFish approach indicate an overfishing status, but ParFish also found a high uncertainty level around $47 \%$.

Conclusion. The use of ParFish algorithm and traditional knowledge can provide qualitatively similar results to conventional models, such as the Beverton-Holt approach. The ParFish approach shows the advantage including confidence intervals to its estimates.
\end{abstract}

Keywords: inland fisheries, maximum sustainable yield, overfishing, small-scale fisheries, ParFish

\section{INTRODUCTION}

The importance of the small-scale fisheries and the inherent challenges for its management are recognized worldwide (Allison and Ellis 2001, Salas et al. 2007, Bené et al. 2010). The status of the inland fishing stocks, however, has received much less attention than marine stocks, in the context of the global crisis of the fisheries (Allan et al. 2005). According to Cooke et al. (2016), inland fisheries has not been addressed by a high-profile global fisheries assessment project. Inland fisheries do not make substantial contribution to Gross Domestic Product (GDP) in comparison to marine fisheries, but the inland fisheries are an important source of jobs and animal protein, mainly for low-income people (Cerdeira et al. 1997, Allan et al. 2005, Bené et al. 2010, Isaac et al. 2015). In short, they could be viewed as provisioning ecosystem services (Dugan et al. 2010).

The stock assessment models, most frequently employed to evaluate the status of exploited inland fish stocks, are based on population dynamic parameters such as growth and mortality rates, which are not generally available. Besides they are population-based parameters and their temporal and spatially dimensions restrict their use to a broader area than those occupied by the population. Similarly, surplus production models also are difficult to employ since robust data series on catch and fishing effort are not available. New fish stock assessment approaches have been developed to deal with the data availability problem associated with small-scale and inland fisheries. These new approaches are mostly based on the acquired knowledge of fishers concerning the exploited resources (Wilson et al. 2003, Medley 2009, Wakeford et al. 2008), an information source that has been increasingly recognized as reliable for detecting changes in catches over time (Philippsen et al. 2016).

Participatory Fisheries Stock Assessment (ParFish) is an approach, based on the traditional knowledge of fishers and other stakeholders, which is capable of developing 
rapid and integrative stock assessments (Medley 2006). Although the catch and effort data series could be included to improve the accuracy, the conceptual baseline is an adaptive cycle of learning, assessment, management planning and development, where fishers' contribution is the key to success (Garaway and Arthur 2005). Bayesian statistics and decision theory are the tools employed to estimate the stock status based on the logistic populational model proposed by Verhulst (Pastor 2008), where the modelling results are expressed as probabilities, thus allowing the incorporation of uncertainties inherent to the fishing. The ParFish approach was tested evaluating several small-scale coral reef fisheries on the coast of Africa and India, which are highly endangered ecosystems. These experiments showed that the ParFish approach could serve as a satisfactory stock assessment procedure (Taylor and Medley 2003, Wakeford et al. 2008).

The fishing that occurs in the Amazon basin is typically a small-scale one, employing different fishing strategies based on fishers' traditional knowledge (Petrere 1978, Batista and Petrere Júnior 2003, Freitas and Rivas 2006). These fisheries use several types of fishing gear and pursue high biodiversity, with more than 200 species or species groups present in landings at the main urban regional centres (Santos et al. 2006). The high fishing intensity has already resulted in an overfishing status for several species, including tambaqui, Colossoma macropomum (Cuvier, 1816) (see Mérona and Bittencourt 1988, Campos et al. 2015); piramutaba, Brachyplatystoma vaillantii (Valenciennes, 1840) (see Barthem et al. 1991); piraiba, Brachyplatystoma filamentosum (Lichtenstein, 1819) (see Petrere et al. 2004); barba chata, Pinirampus pirinampu (Spix et Agassiz, 1829) (see Sant'Anna et al. 2014); and tucunaré, Cichla monoculus Agassiz, 1831 (see Campos and Freitas 2014).

Prochilodus nigricans Spix et Agassiz, 1829, locally known as curimatã, is very abundant and widespread in the Amazon Basin. Its adult population size is strongly correlated with floodplain habitats (Bayley et al. 2018), feeding on detritus composed of fine organic particulates and algae. Prochilodus nigricans is a migratory species and large schools of this fish migrate to spawn at the floodplains adjacent to Amazonian large rivers (Araújo-Lima et al. 2003, Granado-Lorencio et al. 2005). It is the most extensively fished species of the Amazon basin (Batista et al. 2012) with high importance for both subsistence and commercial fisheries. Despite the commercial importance of $P$. nigricans, there are few studies on this particular Amazonian fishery. Santana and Freitas (2013) employed time series analysis on $P$. nigricans landings in the lower Amazon River near Santarém, a city of approximately 100 thousand inhabitants. The presently reported study found a lack of fishing pressure on the younger age groups but with the caveat that the available data do not permit a complete stock assessment. And Bayley et al. (2018) studied the relation between $P$. nigricans abundance and the flood pulse.

Due to the importance of $P$. nigricans to the Amazonian fisheries, our primary objective was to undertake a stock assessment of this species using data collected in the lower stretches of the Solimões and Purus rivers, areas where this fish's stock have been heavily exploited, by at least three decades. And we employed two algorithms of stock assessments. First, we employed a classical yield per recruit model (Beverton and Holt 1993) based on populational dynamic parameters. Following this, we conducted an assessment using the ParFish software, based on the fishers' traditional knowledge. This dual approach was developed to reach the secondary objective of evaluating ParFish as a tool to perform a stock assessment in inland small-scale fisheries by the comparison between the estimated parameters.

\section{MATERIALS AND METHODS}

Study area. Fish landings, fisher behaviour, and fishing dynamics of the Amazonian small-scale fishery of Prochilodus nigricans were studied at the lower reaches of the Solimões and Purus rivers, focusing on the city of Manacapuru (Brazil) as focal area, where fishing landings were monitored and fishers were interviewed (Fig. 1). It is an important fish landing port, receiving the fish production from both a large and complex floodplain system (Lago Grande de Manacapuru) and the lower reaches of the Solimões and Purus rivers (Gonçalves and Batista 2008).

Data sampling and analysis.

Yield per Recruit model. Standard measurements of the lengths of 300 fish were measured monthly, from January 2012 to December 2013, at the main fishing harbour of Iranduba and Manacapuru municipalities. These data were employed (using the ELEFAN I routine on the FISAT software; Gayanillo et al.1996) to estimate the von Bertalanffy (1938) growth equation

$$
L_{t}=L_{\infty}\left[1-e^{-k\left(t_{0}-t\right)}\right]
$$

where $L_{t}$ is the length at the age $t$. The parameter $t_{0}$ was assumed to be 0 , since the initial size of curimatã, Prochilodus nigricans, is negligible and this parameter has no biological meaning. Since $P$. nigricans are vulnerable for fishing immediately after juveniles went to adult stock, the biological recruitment age $\left(T_{\mathrm{r}}\right)$ and the first catch age $\left(T_{\mathrm{c}}\right)$ were assumed as the same and estimated using the von Bertalanffy equation adapted as

$$
\operatorname{Tr}=T c=t_{0}-\left(\frac{1}{k}\right) \operatorname{Ln}\left(1-\frac{L_{t}}{L_{\infty}}\right)
$$

By the same reason, the length at the first catch and mean recruitment length were estimated assuming that $L_{\mathrm{c}}=L_{\mathrm{r}}$ where $L_{\mathrm{c}}$ is the first catch length and $\mathrm{L}_{\mathrm{r}}$ is the biological recruitment length, and equal to the smaller length class fully represented in the sample (King 1995, Sparre and Venema 1997).

The parameters $a$ and $b$ from the weight and length relation: were estimated by non-linear estimation, using 


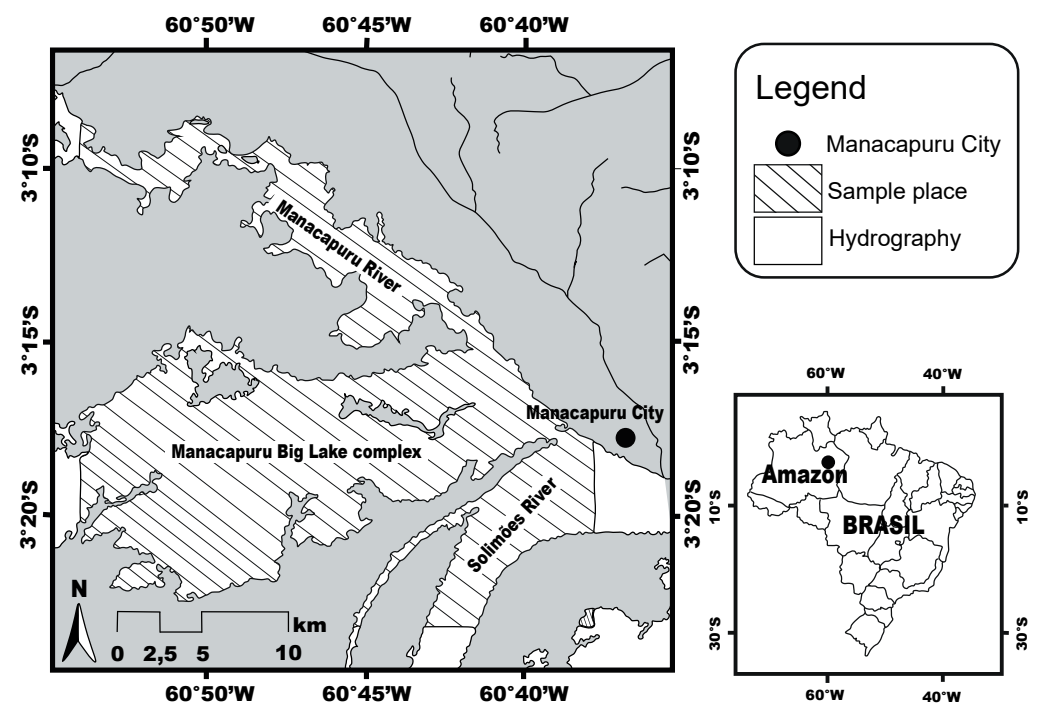

Fig. 1. Study area with an indication of the fish landing centre in Manacapuru city, Amazonas State, Brazil

the Levenberg-Marquardt algorithm of the Statistica software, version 9.0.

The natural mortality was estimated by the equation $M$ $=\left[\ln (1-0.95) \cdot A_{0.95}{ }^{-1}\right]($ Taylor 1958), where the longevity was estimated by $A_{0.95}=t_{0}+2.996 \cdot k^{-1}$. The total mortality $(Z)$ was estimated by the linearized catch curve assuming that the stock density is inversely proportional to the age of the fish (King 1995). The fishing mortality was estimated by the difference between the total mortality and natural mortality $F=Z-M$ and the exploitation rate was calculated as the ratio $E=F \cdot Z^{-1}$.

The yield $(Y)$ per recruit $(R)$ curve was modelled in the fashion of Beverton and Holt (1993) as

$$
\frac{Y}{R}=F \exp \left[-M\left(T_{C}-T_{R}\right)\right] W_{\infty}\left[\left(\frac{1}{Z}\right)-\left(\frac{3 S}{Z+K}\right)+\left(\frac{3 S^{2}}{Z+2 K}\right)-\left(\frac{3 S^{3}}{Z+3 K}\right)\right]
$$

where $F$ is the fishing mortality, $M$ is the natural mortality, $T_{\mathrm{r}}$ is the recruitment age, $T_{\mathrm{c}}=$ first catch age, $W_{\infty}$ is the maximum theoretical weight estimated from the growth equation, $Z$ is the total mortality, $S$ is $e^{-k t c}$, and $k$ is the intrinsic growth rate.

ParFish model. Data employed as input to the ParFish (Participatory Fisheries Stock Assessment, version 2.0; Walmsley et al. 2005) were collected by individual interviews with 48 experienced commercial fishers, who have been working in the $P$. nigricans fisheries in this region for many years. These interviews were conducted by employing an adapted version of the standard questionnaire proposed by the ParFish Manual (Walmsley et al. 2005). An introductory presentation of the ParFish methodology and its objectives were done before the interviews. Subsequently, the fishers were asked questions and each question was two times repeated and the coincidence between answers was checked aiming to assure a complete understanding. Taking into account that there is a recognized seasonal pattern of catch and effort associated with the hydrological cycle (Castello et al. 2015, Pinaya et al. 2016), annual means of these parameters were used into the model. Initial questions were designed to validate the knowledge base of the fisher, as well as to examine fishing locations, gear type, and total catch:

- How many years have you lived in this area?

- How many years have you been fishing in this stretch of the river?

- How many years have you been fishing for curimatã (Prochilodus nigricans)?

- What type of fishing gear have you employed to catch curimatã (Prochilodus nigricans)?

- What do you consider to be the most important widely used types of fishing gear employed to catch curimatã (P. nigricans)?

- On average, how many kilograms of $P$. nigricans do you catch per day?

This was followed by questions concerning the perception of the importance of fishing, as well as questions pertaining to perceptions of changes in catch rate over time (catch rate of the present year, catch rate of the previous year, catch rate at the time of pristine stocks) and recovery time for fish stocks:

- Do you observe changes in the fish production associated with the hydrological cycle?

- If the stock in this stretch of the river were pristine (never been fished), how many kilograms would you be able to catch per day?

- In this situation, do you believe that changes in the fish production would occur?

- If the fishing became forbidden at this stretch of the river, how many years would it take for the fish stock to recover to near the pristine status?

The Participatory Fisheries Stock Assessment Model (ParFish) is a computational package based on Bayesian statistics to do fish stock assessment employing information from fishers. As a Bayesian-based approach, the results 
are presented as probability density functions followed by estimates and confidence intervals of some key estimates such as: Actual Biomass $\left(B_{t}\right)$ : stock size at the time $t$ as a proportion of the pristine biomass; Pristine Biomass $\left(B_{\infty}\right)$ : the carrying capacity of the stock or the maximum size that the stock could reach without fishing; Growth rate $(r)$ : the intrinsic rate of population growth; Catchability coefficient $(q)$ : the proportion of the population caught per fishing effort unit for each type of fishing gear.

The fishing mortality parameter was estimated as the product of the catchability coefficient by the fishing effort or $F=q f($ King 1995).

The catch rates were taken as means

$$
\hat{q} B_{t} j=\left(\hat{q} B_{t} j\right)+\left(\sqrt{N-1} \cdot q B_{t} / \sqrt{N}\right)
$$

Where $q B_{t}$ is the mean catch on the samples.

These values were employed to estimate the parameters associated with each fisher in the logistic model. The intrinsic rate of populational growth $(r)$ was estimated as a non-linear equation. The initial status of the:

$$
X_{1}=X_{0}\left(1+r\left(1-X_{0}\right)\right)
$$

generalized to

$$
\begin{gathered}
X_{T}=X_{T-1}\left(1+r\left(1-X_{T-1}\right)\right) \\
X_{0}=\frac{\hat{q} B_{t}}{\hat{q} B_{\infty}} \\
X_{T}=\frac{U_{1}}{\hat{q} B_{\infty}} \\
\hat{q} B_{\infty}=\frac{U_{1}+U_{2}}{2}
\end{gathered}
$$

where $B_{\infty}$ is the initial status of the stock, assumed as carrying capacity at the logistic model. The catchability was estimated by the catch rate and fishing effort, adjusted by the changes occurring in the stock biomass

$$
\hat{q}=\frac{\left(\frac{\left(\hat{q} B_{t-1}-\hat{q} B_{t}\right)}{S}+r \hat{q} B_{t-1}\right) \cdot\left(1-\frac{\hat{q} B_{t-1}}{\hat{q} B_{\infty}}\right)}{f_{t-1} \cdot \hat{q} B_{t-1}}
$$

Taking the catchability associated with each fishing gear, the pristine stock was estimated as

$$
B_{\infty}=\frac{\hat{q} B_{\infty}}{\hat{q}}
$$

Subsequently, the information on the parameters was reduced to parameters frequency and employed in a logistic model that assumed the biomass is a single variable, giving the estimate of the Maximum Sustainable Yield (MSY) that is the reference target. The model could be viewed as an equation that describes how the population changes over time:

$$
\begin{gathered}
B_{t+1}=B_{t}+r B_{t}\left(1-B_{t} / B_{\infty}\right)-C_{t} \\
C_{g t}=\left(\frac{F_{g}}{\sum g F_{g}}\right)\left(1-e-\sum g F_{g}\right) B_{t} \\
F_{g}=q_{g} f_{g}
\end{gathered}
$$

where $B_{t}$ is the biomass at the time $t, B_{t+1}$ is the biomass at the time $t+1, C_{t}$ is total catch at the time $\mathrm{t} ; C_{g t}$ is the catch associated with each fishing gear $g, g$ is the number of fishing gears employed to produce $C_{g t}, F_{g}$ is the fishing mortality associated with each fishing gear $g, q_{g}$ is the catchability associated with the fishing gear $g$, and $f_{g}$ is the fishing effort associated with the fishing gear $g$.

Then, the status of the stock is defined as a proportion between the current biomass at the time $t$, assumed as $B_{t}$, and the pristine biomass $B_{\infty}$. If this ratio is smaller than $0.5 \mathrm{MSY}$, then it is assumed that the stock is overexploited. By this way, the conservation status of $P$. nigricans stock was estimated as a probability density function with 10000 simulations, assuming a logistic functional form to describe the population and with the actual biomass defined as a proportion of the pristine biomass.

\section{RESULTS}

Yield per Recruit model. The frequency distribution of length was estimated with observations for the 12246 individuals of Prochilodus nigricans that were sampled in 2012 and 2013. The amplitude was $16 \mathrm{~cm}$, for an interval between 18 and $34 \mathrm{~cm}$, with few values higher than 30 $\mathrm{cm}$. The mean lengths and standard deviations were $23.6 \pm 2.33 \mathrm{~cm}$ and $23.4 \pm 2.36 \mathrm{~cm}$, for 2012 and 2013 , respectively. The most abundant length classes were 23, 24 , and $25 \mathrm{~cm}$, for both years. The parameters of the von Bertalanffy growth equation were similar for both years (Table 1).

The yield per recruit curve estimated a $\mathrm{MSY}_{2012}$ of $193.62 \mathrm{~g}$ per recruit for a fishing mortality $F_{\mathrm{MSY}}=1.27$

\section{Table 1}

Populational parameters of the Prochilodus nigricans caught at the lower Solimões River, Amazonas State, Brazil (2012 and 2013)

\begin{tabular}{lcc}
\hline \multicolumn{1}{c}{ Parameter } & 2012 & 2013 \\
\hline Maximum theoretical length $L_{\infty}[\mathrm{cm}]$ & 35.7 & 35.6 \\
Intrinsic growth rate $k$ & 0.65 & 0.57 \\
Longevity A0.95 [year] & 4.53 & 5.25 \\
Natural mortality $M\left[\mathrm{year}^{-1}\right]$ & 0.65 & 0.56 \\
Fishing mortality $F\left[\mathrm{year}^{-1}\right]$ & 1.79 & 1.94 \\
Total mortality $Z\left[\mathrm{year}^{-1}\right]$ & 2.45 & 2.51 \\
Exploitation rate $E$ & 0.73 & 0.77 \\
Age at first catch and age of recruitment & 1.07 & 1.23 \\
$T_{\mathrm{c}}=T_{\mathrm{r}}$ [year] & & \\
\hline
\end{tabular}


year $^{-1}$, which was smaller than the exploitation level corresponding to a fishing mortality equal to $F_{2012}=1.79$ year $^{-1}$ (Fig. 2). These parameters were quite similar in 2013, with a MSY ${ }_{2013}=195.54$ g per recruit for a fishing mortality of $F_{\mathrm{MSY}}=1.1$ year $^{-1}$, which also is smaller than the fishing mortality observed in this year $F_{2013}=1.94$ year-1 (Fig. 3).

ParFish model. The model indicated an overfishing status with a probability of $95 \%$ (Fig. 4). However, the absence of a well-defined peak and the large base are indicating that there is great uncertainty associated with the results.

The large uncertainty is transferred to the stock assessment parameters with large confidence intervals. The Maximum Sustainable Yield was estimated as $32200 \mathrm{t}$ - year ${ }^{-1}$, with an interval between 10700 and 54300 t (Fig.

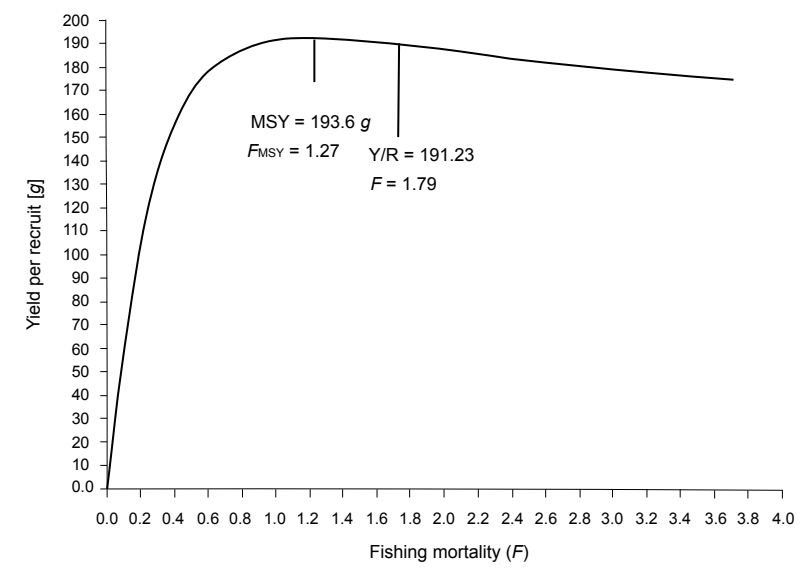

Fig. 2. Yield per Recruit curve estimated for the Prochilodus nigricans caught at the lower Solimões River, Amazonas State, Brazil, in 2012, with indication of the Maximum Sustainable Yield (MSY), the fishing mortality associated with it $\left(F_{\mathrm{MSY}}\right)$, and the observed values of Yield per Recruit (Y/R) and fishing mortality (F2012)

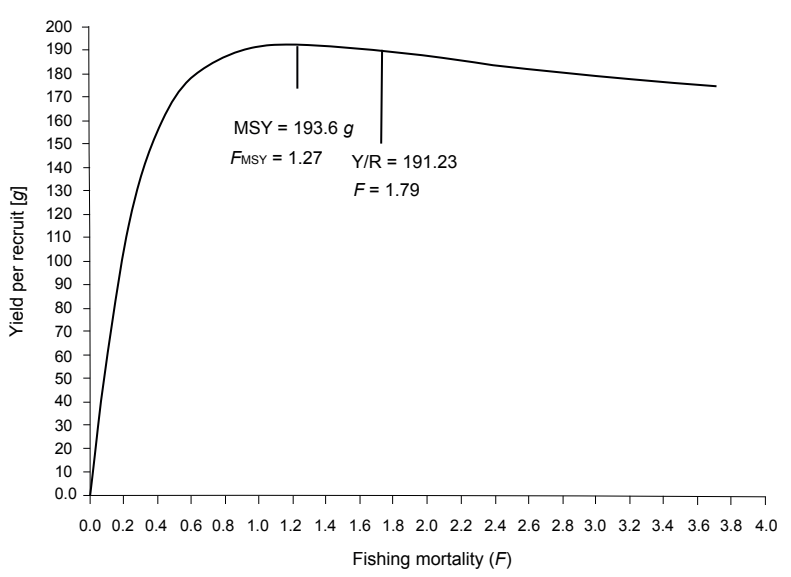

Fig. 3. Yield per Recruit curve estimated for the Prochilodus nigricans caught in the lower Solimões River, Amazonas State, Brazil in 2013, with indication of the Maximum Sustainable Yield (MSY), the fishing mortality associated with it $\left(F_{\mathrm{MSY}}\right)$, and the observed values of Yield per Recruit (Y/R) and fishing mortality (F2013)
5). The modal value of fishing mortality associated with the MSY was $F_{\mathrm{MSY}}=0.37$ year $^{-1}$, with a high confidence interval between 0.043 and 1.161 year $^{-1}$ (Fig. 6).

\section{DISCUSSION}

The population parameters of maximum theoretical length $\left(L_{\infty}\right)$, natural mortality $(M)$ and total mortality $(Z)$ were similar to those found by previous studies for Prochilodus nigricans (see Loubens and Panfili 1995, Ruffino and Isaac 1995, Montreuil et al. 2001, Riofrio 2002, Silva and Stewart 2006, Catarino et al. 2014). Nevertheless, the intrinsic growth rate $(k)$ and the fishing mortality $(F)$ were the largest values ever estimated for this species at the Amazon Basin, including those study that was conducted with the same stock with data from 2011 (Catarino et al. 2014).

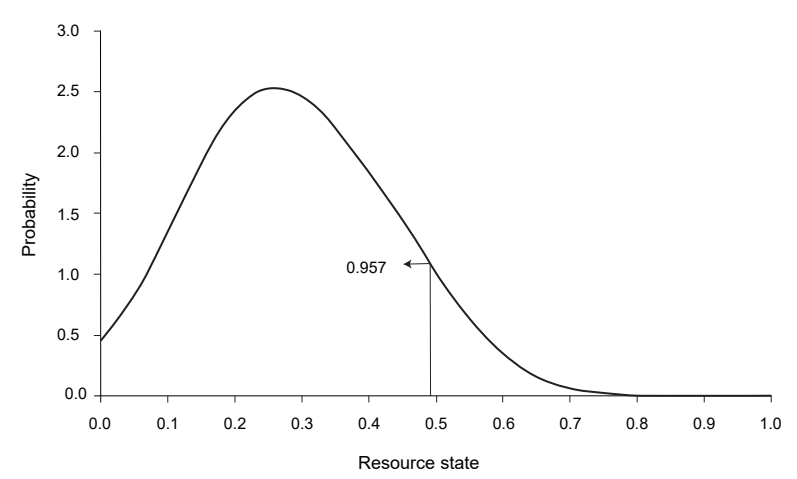

Fig. 4. Probability density function describing the status of Prochilodus nigricans stock (lower Solimões River, Amazonas State, Brazil) in relation to the reference point, which shows that there is greater probability that the actual biomass is smaller than 0.5 of the pristine biomass

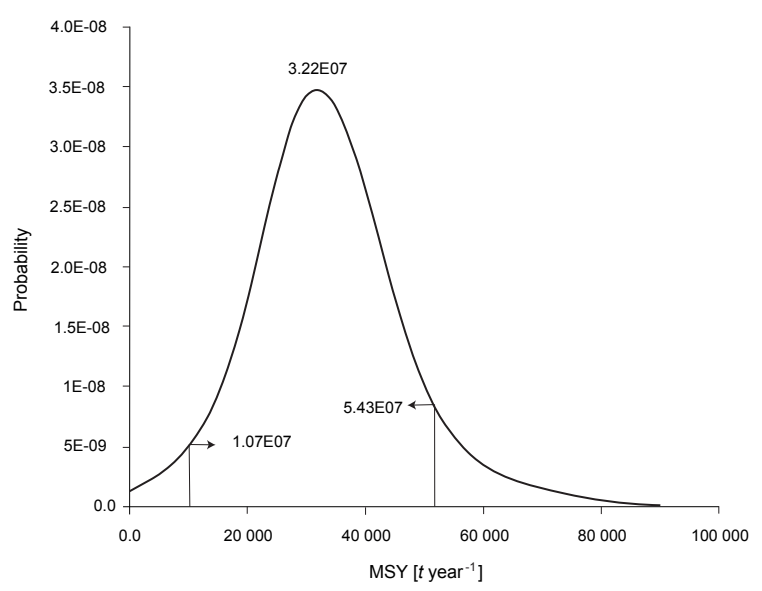

Fig. 5. Distribution of probability to the maximum sustainable yield (MSY) of Prochilodus nigricans caught at the lower Solimões River, Amazonas State, Brazil; the area under the curve indicates the confidence interval of $90 \%$ 


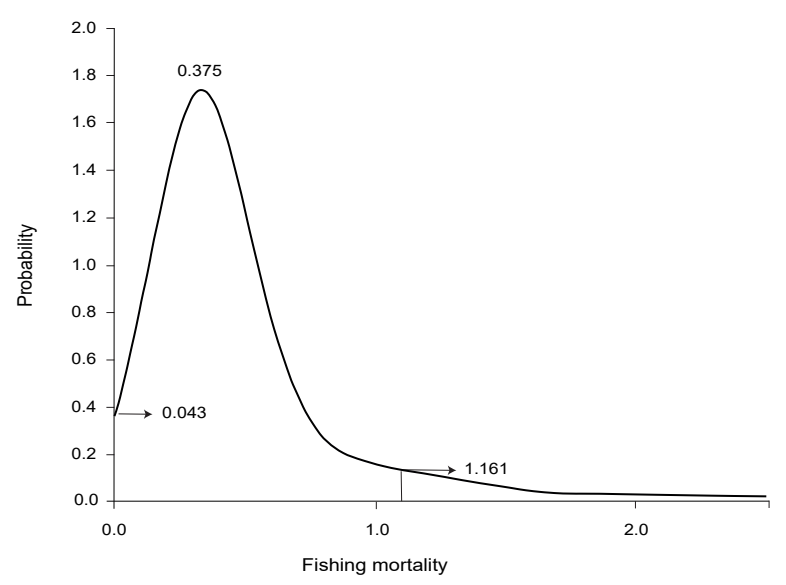

Fig. 6. Distribution of probability of the fishing mortality of Prochilodus nigricans caught at the lower Solimões River, Amazonas State, Brazil, associated with maximum sustainable yield $\left(F_{\mathrm{MSY}}\right)$; the area under the curve indicates the confidence interval of $90 \%$

Fishing pressure on Amazonian fish stocks has been increasing over the last 30 years (Batista et al. 2012), and this is clearly an effect of the increase in fishing mortality. The estimates of maximum yield per recruit generated by the Beverton and Holt curve cannot be directly compared with the maximum sustainable yield estimate generated by the ParFish model, but is noticeable that both approaches indicated that the $P$. nigricans stocks are already overexploited. Nevertheless, the fishing mortalities associated with maximum yields of both models can be compared. The confidence interval generated by the ParFish model estimated that the sustainable fishing mortality should be between 0.04 and 1.16, an interval that encompasses the fishing mortality associated with the MSY for 2013 by the Beverton and Holt curve $\left(F_{\mathrm{MSY}}=1.10\right)$, but not the estimate generated by this method for $2012\left(F_{\mathrm{MSY}}=1.27\right)$.

There is no experience with ParFish method on stock assessment of freshwater fisheries. Wakeford et al. (2008) developed preliminary studies in the Caribbean Sea (near the Turks and Caicos Islands), and the Indian Ocean (near Zanzibar). The Caribbean Sea study conducted a stock assessment of a marine gastropod "Strombus gigas" (valid name Lobatus gigas), employing a combination of a surplus production model and the ParFish software. Both models indicated the existence of overfishing, and the ParFish estimates showing higher uncertainty. Similar levels of uncertainty were obtained for the stocks of Etelis oculatus (Valenciennes, 1828) and Lutjanus vivanus (Cuvier, 1828), exploited by small-scale fishers around Zanzibar Island, but the probability of overfishing was smaller than $50 \%$. A common characteristic between our results and the other studies is the high uncertainty associated with the estimates. However, this is to be expected since this is the first application of this type of approach and likely incorporates a smaller number of interviews. Moreover, high stochasticity is a common characteristic of fisheries (Ludwig et al. 1993, Charles 1998).
The development of policy to support small-scale and subsistence fisheries is often made difficult because of a critical lack of knowledge about stock sizes and the population dynamics of the species associated with these species. As noted, spatial dispersion and geographic variation complicate this task. The use of traditional fisher knowledge to help with stock assessments has been implemented using the ParFish model in smallscale marine fisheries. To our knowledge, our research is the first to apply this model to small-scale freshwater fisheries. However, much research remains to be done before the method can be generally applied to support policy decisions. In particular, research must be conducted of the sensitivity of user-reported knowledge to the survey approach that is used to ascertain this information. In particular, are the results sensitive to reference points, the order of questions, the units in which fish biomass are expressed, and the importance of visual aids in helping respondents compare magnitudes, particularly when the magnitudes are presented as percentages. In addition, it would be interesting to know how the quantities expressed by respondents are sensitive to socio-economic variables. For example, do older fishers think that pristine stocks are bigger than what younger fishers would report? Do more successful fishers have different estimates than less successful? Do we see differences by gender, educational status, or whether the fisher is active full time or part time?

Another area in which research would be helpful would be to conduct parallel traditional-knowledge surveys and field assessments of field stocks. This could determine potential relations between the two sets of information, allowing for better use of traditional knowledge in areas where there are no conventional stock assessments. Finally, the uncertainty level could be reduced by increasing the number of interviews (Walmsley et al. 2005), but how big should sample size be? There is a need for research associated with the relation between sample size and uncertainty so that research funds can be used most effectively in conducting stock assessments using traditional knowledge.

\section{ACKNOWLEDGEMENTS}

CECF was funded by CNPq (grant 302807/2015-2) and FINEP (PIATAM Project; JRK was funded by a Lenfest grant from Washington and Lee University and by the Hendon Professorship Endowment.

\section{REFERENCES}

Allan J.D., Abell R., Hogan Z., Revenga C., Taylor B.W., Welcomme R.L., Winemiller K.O. 2005. Overfishing of inland waters. Bioscience 55 (12): 1041-1051. DOI: 10.1641/0006-3568(2005)055[1041:OOIW]2.0.CO;2

Allison E., Ellis F. 2001. The livelihood approach and management of small-scale fisheries. Marine Policy 25 (5): 377-388. DOI: 10.1016/S0308-597X(01)00023-9

Araújo-Lima C.A.R.M., Ruffino M.L. 2003. Migratory fishes of the Brazilian Amazon. Pp. 235-307. In: Carolsfeld J., Harvey B., Ross C., Baer A. (eds.) Migratory fishes of South America: Biology, fisheries 
and conservation status. World Fisheries Trust, World Bank, International Development and Research Centre (IDRC), Montreal, Canada.

Barthem R.B., Ribeiro M.C.L.B., Petrere M.jr. 1991. Life strategies of some long-distance migratory catfish in relation to hydroelectric dams in the Amazon basin. Biological Conservation 55 (3): 339-345. DOI: 10.1016/0006-3207(91)90037-A

Batista V.S., Isaac V.J., Fabré N.N., Gonzales J.C.A., Almeida O., Rivero S., Oliveira Júnior J.N. 2012. Peixes e pesca no Solimões Amazonas: uma avaliação integrada. [Fish and fishing in Solimões Amazonas: an integrated assessment.] Instituto Brasileiro do Meio Ambiente e dos Recursos Naturais Renováveis, IBAMA/ProVárzea, Brasília, Brazil. [In Portuguese.]

Batista V.S., Petrere Júnior M. 2003. Characterization of the commercial fish production landed at Manaus, Amazonas State, Brazil. Acta Amazonica 33 (1): 5366. DOI: 10.1590/1809-4392200331066

Bayley P.B., Castello L., Batista V.S., Fabré N.N. 2018. Response of Prochilodus nigricans to flood pulse variation in the central Amazon. Royal Society Open Science 5 (6): e172232. DOI: 10.1098/rsos. 172232

Béné C., Hersoug B., Alison E.H. 2010. Not by rent alone: Analysing the pro-poor functions of smallscale fisheries in developing countries. Development Policy Review 28 (3): 325-358. DOI: 10.1111/j.14677679.2010.00486.x

Beverton R.J.H., Holt S.J. 1993. On the dynamics of exploited fish populations. Fish and Fisheries Series Vol. 11, Springer Netherlands, Dordrecht, The Netherlands. DOI: 10.1007/978-94-011-2106-4

Campos C.P., Freitas C.E.C. 2014. Yield per recruit of the peacock bass Cichla monoculus (Spix and Agassiz, 1831) caught in Lago Grande at Manacapuru (Amazonas-Brazil). Brazilian Journal of Biology 74 (1): 226-230. DOI: 10.1590/1519-6984.17312

Campos C.P., Garcez R.C.S., Catarino M.F., Costa G.A., Freitas C.E.C. 2015. Population dynamics and stock assessment of Colossoma macropomum caught in the Manacapuru Lake system (Amazon Basin, Brazil). Fisheries Management and Ecology 22 (5): 400-406. DOI: 10.1111/fme.12139

Castello L., Isaac V.J., Thapa R. 2015. Flood pulse effects on multispecies fishery yields in the lower Amazon. Royal Society Open Science 2 (11): e150299. DOI: 10.1098/rsos. 150299

Catarino M.F., Campos C.P., Garcez R., Freitas C.E.C. 2014. Population dynamics of Prochilodus nigricans caught in Manacapuru Lake (Amazon Basin, Brazil). Boletim do Instituto de Pesca 40 (4): 589-595.

Cerdeira R.G.P., Ruffino M.L., Isaac V.J. 1997. Consumo de pescado e outros alimentos pela população ribeirinha do Lago Grande de Monte Alegre, PA-Brazil. [Fish consumption and others food items by the riverine population of the Lago Grande de Monte Alegre, PA-Brazil.] Acta Amazonica 27 (3): 231-237. [In Portuguese.] DOI: 10.1590/180943921997273228
Charles A.T. 1998. Living with uncertainty in fisheries: Analytical methods, management priorities, and the Canadian ground fishery experience. Fisheries Research 37 (1-3): 37-50. DOI: 10.1016/S01657836(98)00125-8

Cooke S.J., Allison E.H., Beard T.D., Arlinghaus R., Arthington A.H., Bartley D.M., Cowx I.G., Fuentevilla C., Leonard N.J., Lorenzen K., Lynch A.J., Nguyen V.M., Youn S.-J., Taylor W.W., Welcomme R.L. 2016. On the sustainability of inland fisheries: Finding a future for the forgotten. Ambio 45 (7): 753-764. DOI: 10.1007/s13280-016-0787-4

Dugan P., Delaporte P., Andrew N., O'Keefe M., Welcomme R. 2010. Blue harvest: Inland fisheries as an ecosystem service. UNEP. WorldFish Center, Penang, Malaysia.

Freitas C.E.C., Rivas A.A.F. 2006. A pesca e os recursos pesqueiros na Amazônia ocidental. [Fishing and fishing resources in the western Amazon.] Ciência e Cultura 58 (3): 30-32. [In Portuguese.]

Garaway C.J., Arthur R.I. 2004. Adaptive learning: A practical framework for the implementation of adaptive co-management. Lessons from selected experiences in South and Southeast Asia. MRAG, London, UK.

Gayanillo J.R., Sparre F.C.P., Pauly D. 1996. Stock assessment tools - User's manual. FAO, Rome.

Gonçalves C., Batista V.S. 2008. Avaliação do desembarque pesqueiro efetuado em Manacapuru, Amazonas, Brasil. [Evaluation of the Manacapuru fishing landing, Amazonas State, Brazil.] Acta Amazonica 38 (1): 135-144. [In Portuguese.] DOI: 10.1590/S0044-59672008000100015

Granado-Lorencio C., Araújo Lima C.R.M., LobónCerviá J. 2005. Abundance - distribution relationships in fish assembly of the Amazonas floodplain lakes. Ecography 28 (4): 515-520. DOI: 10.1111/j.09067590.2005.04176.x

Isaac V.J., Almeida M.C., Giarrizzo T., Deus C.P., Vale R., Klein G., Begossi A. 2015. Food consumption as indicator of the conservation of natural resources in riverine communities of the Brazilian Amazon. Anais da Academia Brasileira de Ciências 87 (4): 1-14. DOI: 10.1590/0001-3765201520140250

King M. 1995. Fisheries biology, Assessment and management. Fishing New Books. Oxford, UK.

Loubens G., Panfili J. 1995. Biologie de Prochilodus nigricans (Teleostei: Prochilodontidae) dans le bassin du Mamoré (Amazonie bolivienne). Ichthyological Explorations of Freshwater 6 (1): 17-32.

Ludwig D., Hilborn R., Walters C. 1993. Uncertainty, resource exploitation, and conservation: Lessons from history. Science 260 (5104): 17-36. DOI: 10.1126/ science. 260.5104 .17

Medley P. 2006. [9.] ParFish-Participatory fisheries stock assessment. Pp. 149-162. In: Hoggarth D.D., Abeyasekera S., Arthur R., Beddington J.R., Burn R.W., Halls A.S., Kirkwood G.P., McAllister M., Medley P., Mees C.C., Parkes G.B., Pilling G.P., Wakeford R.C., Welcomme R.L. Stock Assessment 
for Fishery Management - A framework guide to the use of the fish stock assessment tools of the Fisheries Management Science Programme. FAO Fisheries Technical Paper No. 487. Rome, Italy.

Medley P. 2009. Tools to conduct a participatory fishery (ParFish) assessment using Bayesian decision analysis. Pp. 237-245. Proceedings of the 61st Gulf and Caribbean Fisheries Institute. 10-14 November 2008, Gosier, Guadeloupe, French West Indies.

Mérona B., Bittencourt M.M. 1988. A pesca na Amazônia através dos desembarques no mercado de Manaus: resultados preliminares. [Amazon fishing through landings in the Manaus market: Preliminary results.] Memória Sociedad Ciências Naturales La Salle 48 (Suppl.): 433-453. [In Portuguese.]

Montreiul V., García A., Rodríguez C. 2001. Biología reproductiva de «boquichico», Prochilodus nigricans, en la Amazonía Peruana. Folia Amazónica 12 (1-2): 5-13. DOI: 10.24841/fa.v12i1-2.122

Pastor J. 2008. Mathematical ecology of populations and ecosystems. John Wiley and Sons. Hong Kong.

Petrere M.jr. 1978. Pesca e esforço de pesca no Estado do Amazonas. I. Esforço e captura por unidade de esforço. [Fishing and fishing effort in the State of Amazonas. I. Effort and capture per unit of effort.] Acta Amazonica 8 (3): 439-454. [In Portuguese.] DOI: 10.1590/180943921978083439

Petrere M.jr., Barthem R.B., Córdoba E.A., Gómez B.C. 2004. Review of the large catfish fisheries in the upper Amazon and the stock depletion of piraiba (Brachyplatystoma filamentosum Lichtenstein). Reviews of Fish Biology and Fisheries 14 (4): 403414. DOI: $10.1007 / \mathrm{s} 11160-004-8362-7$

Philippsen J.S., Minte-Vera C.V., Okada E.K., Carvalho A.R., Angelini R. 2016. Fishers' and scientific histories: An example of consensus from an inland fishery. Marine and Freshwater Research 68 (5): 980-992. DOI: 10.1071/MF16053

Pinaya W.H.D., Lobon-Cervia F.J., Pita P., Souza R.B., Freire J., Isaac V.J. 2016. Multispecies fisheries in the lower Amazon River and its relationship with the regional and global climate variability. PlosOne 11 (6): e0157050. DOI: 10.1371/journal.pone.0157050

Riofrío J.C.Q.2002. Aspectos biométricos y reproductivos de boquichico Prochilodus nigricans Agassiz, 1829 (Pisces: Prochilodontidae) en Ucayali, Perú. Revista Peruana de Biologia 9 (2): 111-115. DOI: 10.15381/ rpb.v9i2.2529

Ruffino M.L., Isaac V.J. 1995. Life cycle and biological parameters of several Brazilian Amazon fish species. NAGA, the ICLARM Quarterly 18 (4): 41-45.

Salas S., Chuenpagdee R., Seijo J.C., Charles A. 2007. Challenges in the assessment and management of small-scale fisheries in Latin America and the
Caribbean. Fisheries Research 87 (1): 5-16. DOI: 10.1016/j.fishres.2007.06.015

Santana I.F., Freitas C.E.C. 2013. A time series analysis of Prochilodus nigricans landings caught by smallscale fisheries in the lower stretch of the Amazon River. Brazilian Journal of Biology 73 (1): 1-7. DOI: 10.1590/S1519-69842013000100007

Sant'Anna I.R.A., Doria C.R., Freitas C.E.C. 2014. Pre-impoundment stock assessment of two Pimelodidae species caught by small-scale fisheries in the Madeira River (Amazon Basin-Brazil). Fisheries Management and Ecology 21 (4): 322-329. DOI: 10.1111/fme. 12082

Santos G.M., Ferreira E., Zuanon J.A.S. 2006. Peixes comerciais de Manaus. [Commercial fish of Manaus.] IBAMA/AM, ProVárzea. Manaus, Brazil. [In Portuguese.]

Silva E.A., Stewart D.J. 2006. Age structure, growth and survival rates of the commercial fish Prochilodus nigricans (bocachico) in north-eastern Ecuador. Environmental Biology of Fishes 77 (1): 63-77. DOI: 10.1007/s10641-006-9055-y

Sparre P., Venema S.C. 1997. Introdução à avaliação de mananciais de peixes tropicais. Parte 1: Manual. [Introduction to tropical fish stock assessment. Part 1: Manual.] FAO, Roma, Italy. [In Portuguese.]

Taylor C.C. 1958. Cod growth and temperature. Journal of Conseil International for 1' Exploration de la Mer 23 (3): 366-370. DOI: 10.1093/icesjms/23.3.366

Taylor O., Medley P. 2003. Turks and Caicos Islands: Field report. R7947 Participatory Fisheries Stock Assessment. Marine Resources Assessment Group, London, UK.

von Bertalanffy L. 1938. A quantitative theory of organic growth (Inquiries on growth laws. II). Human Biology 10 (2): 181-213.

Wakeford R.C., Walmsley S.F., Trumble R.J., Medley P.A.H. 2008. Improving management of coral reefs fisheries in data limited situations: Experiences from the ParFish methodology. Proceedings of the 11th International Coral Reef Symposium, 7-11 July 2008. Ft. Lauderdale FL, USA.

Walmsley S., Howard C.A., Medley P.A.H. 2005. Participatory Fisheries Stock Assessment (ParFish) guidelines. Marine Resources Assessment Group (MRAG), London, UK.

Wilson D.C., Nielsen J.R., Degnbol P. (eds.) 2003. The fisheries co-management experience: Accomplishments, challenges and prospects. Kluwer Academic Publishers. Dordrecht, The Netherlands. DOI: $10.1007 / 978-94-017-3323-6$

Received: 23 December 2018 Accepted: 26 July 2019 Published electronically: 15 December 2019 